\title{
Understanding price competition in the German motor insurance market
}

\author{
Martin Eling • Michael Luhnen
}

Published online: 3 October 2008

(C) Springer-Verlag 2008

\begin{abstract}
This paper analyzes price competition in the German motor insurance market since 1994 and looks for evidence to back up a claim frequently found in the trade literature - that there have been two recent price wars in this industry, the first in 1996-1999, the second in 2005-2006. In a first step, we analyze the development of the German motor insurance market and compare it to that of other property-liability lines of business. In a second step the applicability of price war definitions found in the marketing literature to the German motor insurance market is checked. In a third step, a comparison to reference cases from other industries, where price wars have been subject to academic analysis, is conducted to complement the analysis. We conclude that, contrary to reports in the trade literature, the periods of 1996-1999 and 2005-2006 should be considered as times of intense competition in the motor insurance industry, not as times of price war.
\end{abstract}

Zusammenfassung In dieser Arbeit untersuchen wir den Preiswettbewerb im deutschen Kraftfahrzeugversicherungsmarkt seit der Deregulierung der Versicherungsmärkte im Jahr 1994. Im Zentrum der Analyse steht die häufig in der Fachpresse zu findende Aussage, dass in diesem Versicherungszweig zwei Preiskriege stattgefunden haben: Der erste von 1996 bis 1999 und der zweite von 2005 bis 2006. Im ersten Schritt untersuchen wir die Entwicklung des deutschen Kraftfahrzeugversicherungsmarkts im Vergleich zu anderen Zweigen der Schadenversicherung. Im zweiten Schritt prüfen wir gängige Preiskrieg-Definitionen aus der Marketing-Literatur hinsichtlich ihre Anwendbarkeit auf den deutschen Kraftfahrzeugversicherungsmarkt.

\footnotetext{
M. Eling (『) - M. Luhnen

University of St. Gallen, Institute of Insurance Economics,

Kirchlistrasse 2, 9010 St. Gallen, Switzerland

E-Mail: martin.eling@unisg.ch
} 
Schließlich nehmen wir einen Vergleich mit Preiskriegen aus anderen Industrien vor. Im Gegensatz zur Fachpresse kommen wir zu der Schlussfolgerung, dass die zwei Zeiträume nicht als Phasen des Preiskrieges, sondern eher als Phasen intensiven Wettbewerbs zu interpretieren sind.

\section{Introduction}

The aim of this paper is to analyze competition in the German motor insurance market after deregulation of the European Union insurance markets in 1994. The 1994 deregulation brought about a fundamental change in the market conditions for the German insurance industry. Prior to 1994, the insurance business was embedded in a dense regulatory network, with mostly uniform products, tariffs, and limited competition. After deregulation, market transparency increased and it became easier for foreign competitors to enter the market, resulting in intensive price competition, margin erosion, and cost pressure (see Farny 1999 and Hussels et al. 2005).

The motor insurance market is the biggest line of business in the German propertyliability market with a premium volume of $€ 21$ billion (2006), i. e., $36 \%$ of the total property-liability premium volume (see BaFin 2007). Due to its high strategic importance as a "door opener" to selling other property-liability and life insurance products, this line of business was one of the first to experience intense competition after 1994. In the first few years following deregulation, trade literature repeatedly used terms such as "price war," "heavy discounting," and "buying market share at any price" when discussing motor insurance in Germany (see, e. g., Reitz 1999; Seiwert 2006; pp. 92-93 in GDV 2005). Many practitioners believe that there have actually been two "price wars" in this industry: The first occurring two years after deregulation from 1996 to 1999, and the second started at the end of 2004 and became evident in the data from 2005 to 2006 . $^{1}$ Along with its price war reports, trade literature regularly claimed that immense value destruction had resulted from the intense competition, e.g., a value destruction of $€ 7$ billion is reported by industry experts for the period from 1996 to 1999 (see Erdönmez et al. 2007).

In this paper we analyze competition in the German motor insurance market since 1994, looking for evidence to support the price war hypothesis often presumed in the trade literature. We first analyze market development of German motor insurance and compare it to the development of other property-liability lines of business. We then deepen our analysis by testing existing price war definitions from the marketing literature against the German motor insurance market. ${ }^{2}$ The comparison to reference cases on price wars in other (nonfinancial services) industries complements our analysis.

We find that the German motor insurance market is, indeed, experiencing intense price competition. However, the industry's situation does not match all the market characteristics and, particularly, the characteristics of other industries, that are thought

\footnotetext{
${ }^{1}$ According to Lier (2008), the second price war period extends beyond 2006 and may even be continuing into the present. However, due to data availability, we restrict our analysis to the time period until end of 2006.

${ }^{2}$ For the price war definitions, see Heil and Helsen (2001). 
to be indicative of a price war. We thus conclude that the market environment in German motor insurance during the periods 1996-1999 and 2005-2006 does not fit into common definitions of price wars and rather should be described as intense competition.

Our results are of great interest for managers as well as regulators, especially as they are in contrast to the commonly held opinion on this market reported in trade literature. The results thus give new insights into the development of and the competition in the German motor insurance market, for both academics and practitioners.

The remainder of the paper is organized as follows. Section 2 provides an overview of the German motor and property-liability insurance markets. Section 3 analyzes whether insurers' pricing behavior since deregulation can be considered a price war or just intense competition by testing price war definitions from marketing literature and reference cases from other industries. Section 4 concludes.

\section{Overview of German motor insurance market}

After years of continuous growth and steady profits in a regulated market environment, a series of European Commission directives on insurance markets in 1994 fundamentally changed the market conditions for the German insurance industry. The abolition of price regulation ("cost-plus approach") enabled insurers to set and change rates freely, which led to increased competition as well as price pressures. Moreover, insurers were enabled to compete on products and contract conditions, since the exante approval requirement through the regulator was abolished as well. Previously in the motor insurance business, terms had been standardized along the lines laid down by the regulator, so that before deregulation, all insurers were basically selling the same product. Deregulation also opened the German market to foreign competitors; prior to 1994, foreign insurers had had a market share of less than 5\% (see Rees et al. 1999).

Table 1 illustrates price competition in the German motor insurance market and highlights the trend toward consolidation in the industry. In Panel A, we set out the number of companies, the number of contracts, and gross premiums earned, as well as the loss ratio and technical result for the property-liability insurance market for the period 1994-2006. To reduce reporting distortions regarding the loss ratio, we use the loss ratio excluding the result from processing of unsettled claims from the previous year, since this result only concerns historical claims, not claims from the actual year. ${ }^{3}$ Panel B shows the motor insurance market, which represents, in terms of premiums, approximately 44\% (1994) to 36\% (2006) of the total property-liability market. The remaining 56\% (1994) to 64\% (2006) of the market is summarized in Panel C as other property-liability insurers. We obtained the data in Panels A and B from the regulatory annual statements, Table 541, filed with the German Federal Financial Supervisory Authority (BaFin) and subsequently imputed data into Panel C. Additionally, we obtained the data on numbers of vehicles from the annual reports of the German Insurance Association (GDV). Note that although it is common to

\footnotetext{
${ }^{3}$ See Morawetz (2008) for a similar approach.
} 


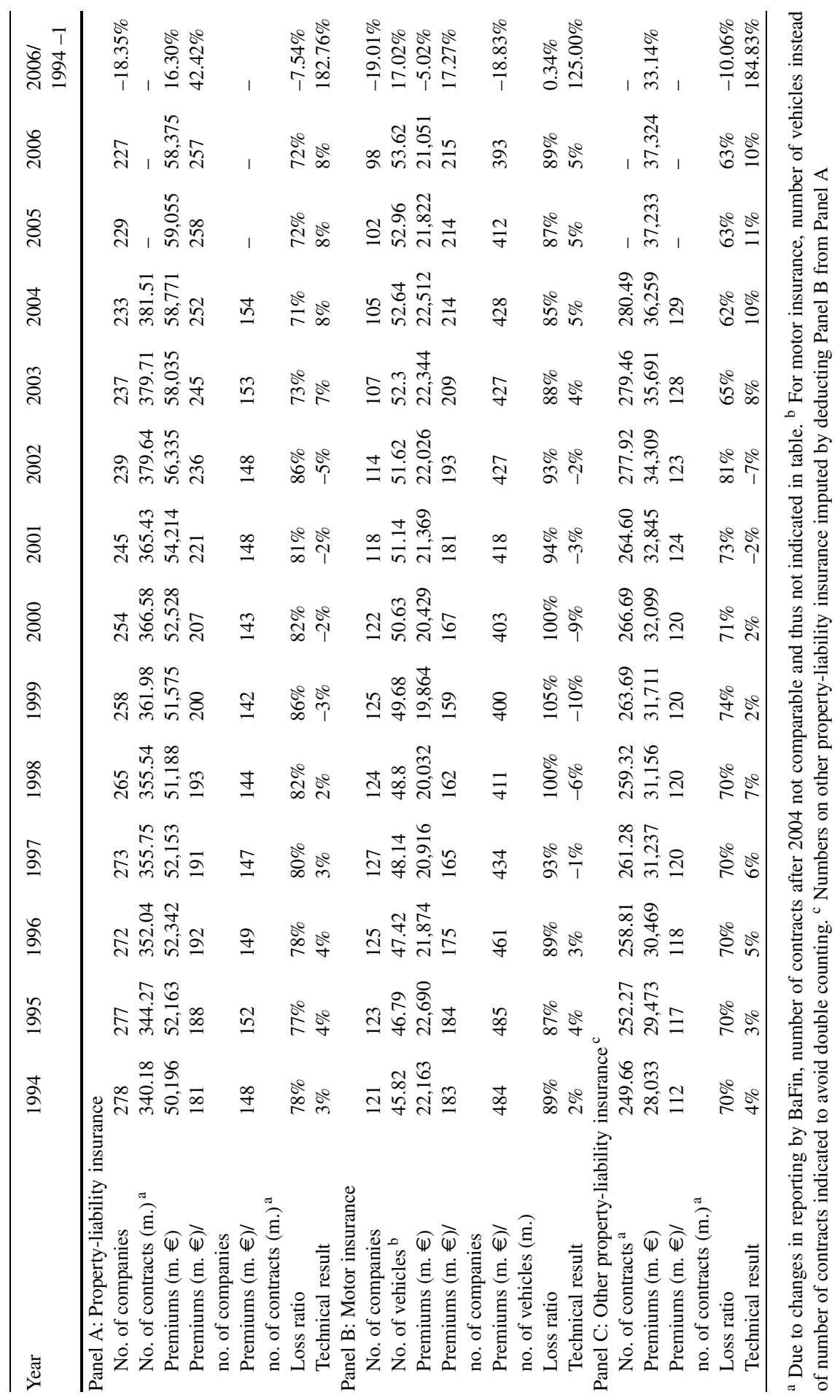


distinguish among third-party liability and collision within motor insurance, Table 1 focuses on the motor insurance market as a whole. ${ }^{4}$

\subsection{Market structure}

The number of companies decreased over the analyzed time period by about $18 \%$ in the property-liability market and by about $19 \%$ in motor insurance. However, in the property-liability market, even though the number of insurers decreased, the total premiums increased by $16 \%$. In contrast, motor insurance premium volume decreased about $5 \%$ from 1994 to 2006 . We consider the ratio of premiums to the number of companies as an indicator of consolidation in the insurance industry. At the total industry level, the premiums per company increased by 42\% from 1994 to 2006 (from $€ 181$ million to $€ 257$ million). Although premium volume declined in motor insurance, the premiums per company rose by $17 \%$ during the period of investigation, which emphasizes the trend toward consolidation and concentration in the German insurance industry. This trend becomes even more obvious when looking at the market share of the top-10 property-liability and motor insurers: in 1994, the 10 biggest property-liability insurers had a market share of $37 \%$ (motor: $45 \%$ ); in 2006, they had a market share of $47 \%$ (motor: $52 \%$ ). ${ }^{5}$

\subsection{Premiums}

In the motor insurance market, two phases of significant premium decline can be identified: the first occurred between 1996 and 1999 and the second between 2005 and 2006. Figure 1 is a graphical illustration of these declines and also shows how the rest of the property-liability insurance market was doing during the same periods. The two premium declines were the main motivation behind reports of a price war in the German trade literature (see, e. g., Schmidt-Gallas et al. 2005).

Figure 1 shows a cyclical pattern in premium growth comparable to the underwriting cycle (see, e. g., Cummins and Outreville 1987). Considering the other propertyliability insurance lines of business, premium growth is positive across the entire period of investigation, but it is negative for six years in the case of motor insurance. Also, the observed cyclical pattern is more accentuated for motor insurance than it is for other property-liability.

Figure 2 shows the development of premiums per vehicle (for the motor insurance market) and of premiums per contract (for the remainder of the property-liability market). For comparison purposes, the values have been standardized to 100 in 1994 . However, BaFin changed its statistics on the number of contracts in property liability in 2005, so that values after 2004 are not comparable and, consequently, are not shown in Fig. 2. For the motor insurance market, we see a steady decline in premiums per vehicle since 1994 with a slight growth in average premiums for 1999-2004. In contrast, average premiums increase slowly, but steadily, for the other propertyliability lines of business. Figure 2 shows even more clearly than Fig. 1 that the motor

\footnotetext{
${ }^{4} \mathrm{An}$ analysis of different segments of the motor insurance market is available from the authors upon request.

${ }^{5}$ This analysis is also available from the authors upon request.
} 


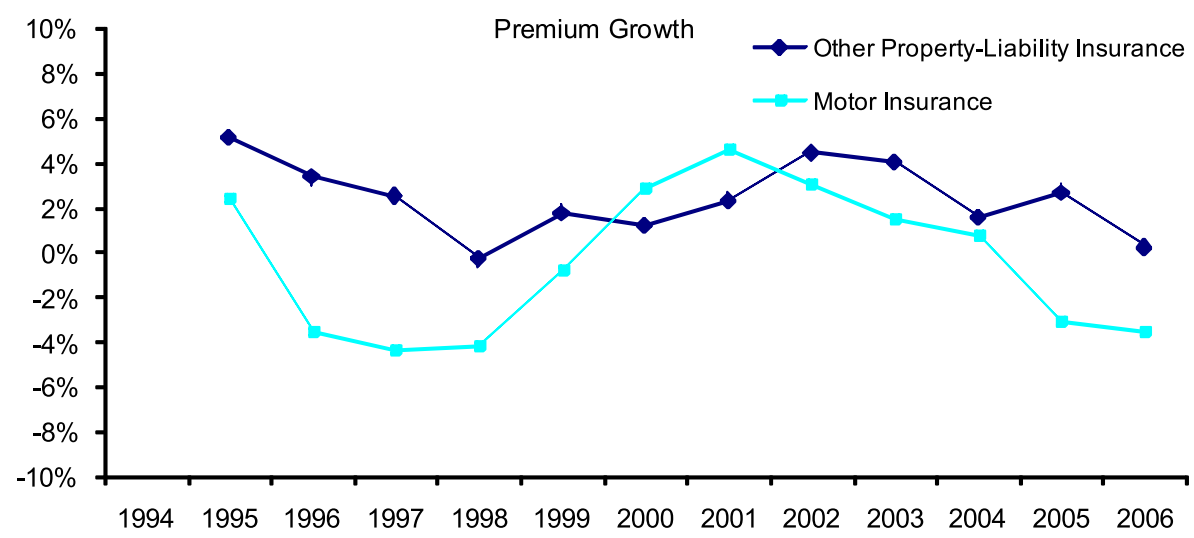

Fig. 1 Premium growth in the German property-liability insurance market

Premium per contract/vehicle (standardized to 100 in 1994)

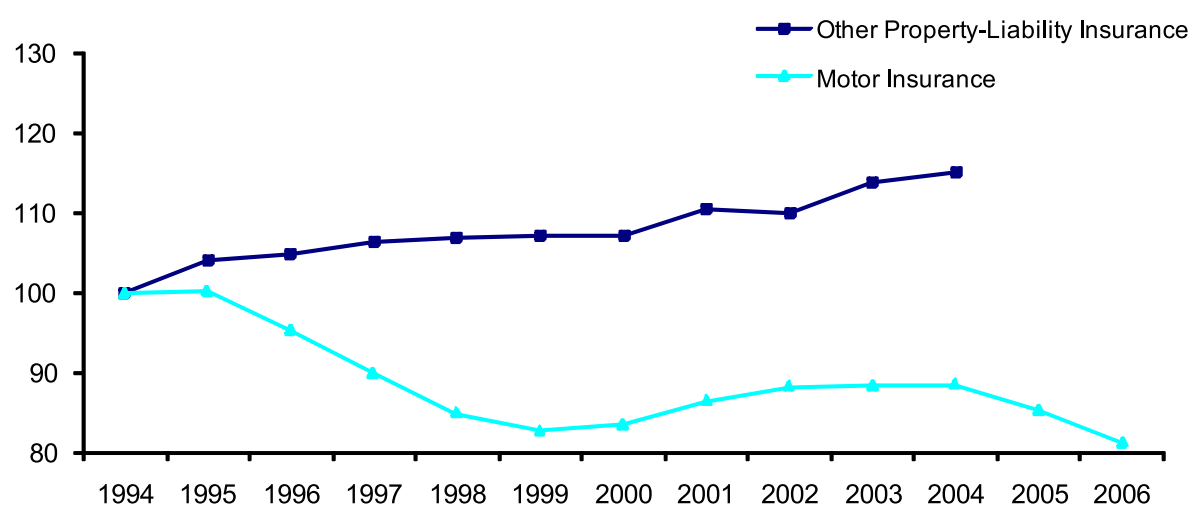

Fig. 2 Premiums per contract in the German property-liability insurance market

insurance market is subject to significant pressure on premium income compared to the rest of the property-liability insurance market. In the light of the steadily increasing number of vehicles insured (increase of 17\%, from 45.8 million in 1994 to 53.6 million in 2006) and declining total premiums (decrease of $5 \%$ for the period shown above), average premiums declined quickly. In fact, in 2006 they were nearly 19\% below the level of 1994 and even lower than in 1999.

\subsection{Profitability}

Figure 3 illustrates the profitability of German motor insurance and other propertyliability lines of business. For the six years from 1997 to 2002, the technical result in the motor insurance market is negative. ${ }^{6}$ In contrast, the other property-liability lines

\footnotetext{
${ }^{6}$ This observation is in line with Morawetz (2008), who uses actuarial models to estimate actual technical results for motor insurance versus reported technical results as indicated in Fig. 3. 


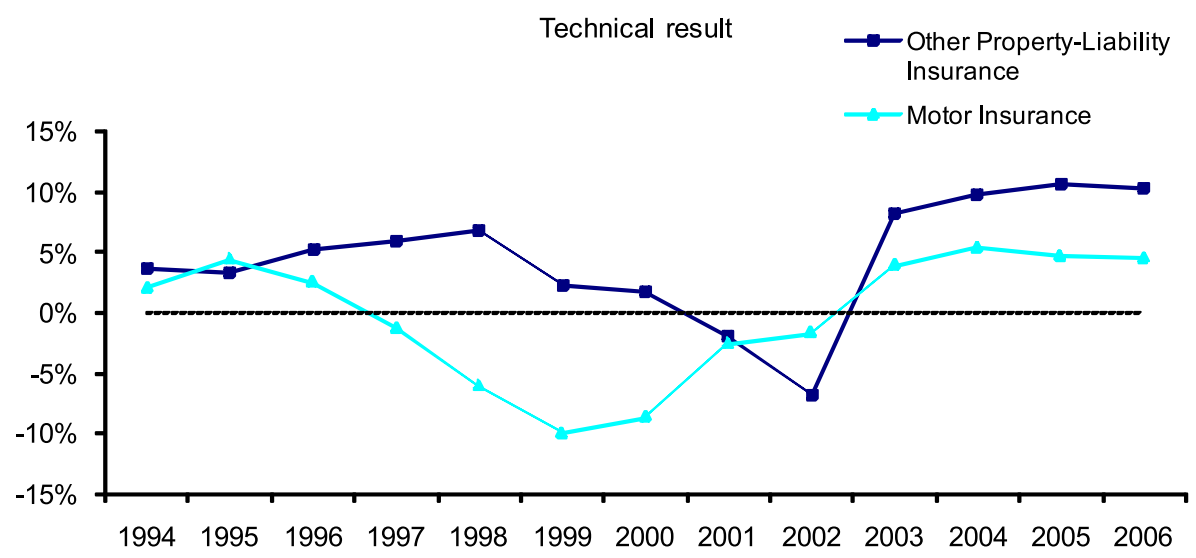

Fig. 3 Technical result of German property-liability insurance market

Premiums and losses (standardized to 100 in 1994)

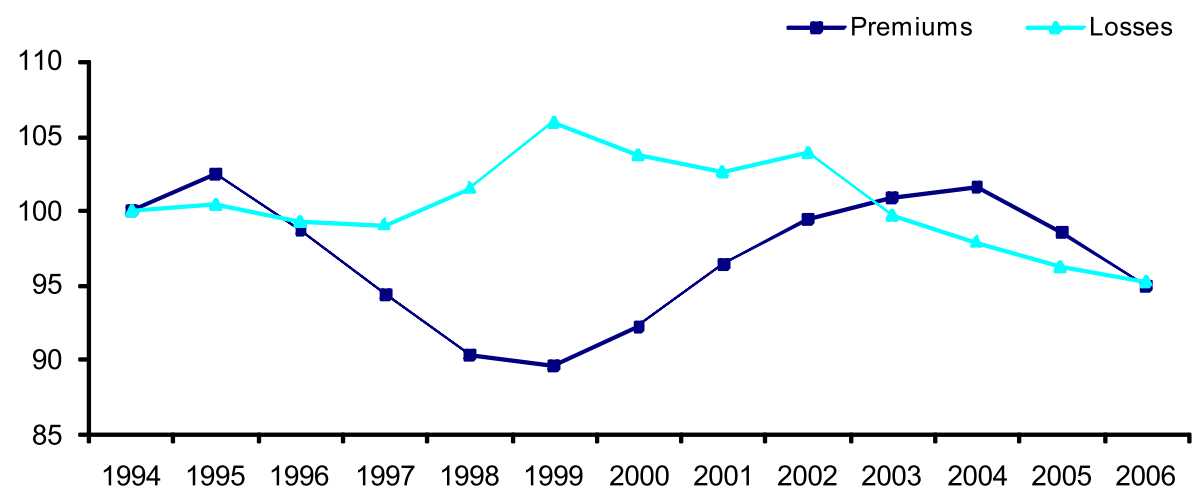

Fig. 4 Premiums and losses in the German motor insurance market

of business operated profitably each year, i. e., with positive technical results, with the exception of 2001 and 2002.

A separate analysis of premiums and losses for the motor insurance market (see Fig. 4) provides an even clearer picture of the competitive situation and dynamics in this market segment. For the period 1996 to 1999, premiums declined steadily and loss payments steadily grew. Only starting in 2000, was this trend reversed; however, it was not until 2003 that premiums and losses returned to 1994 levels. The situation in 2005 and 2006, however, was different. Losses and premiums both clearly and continuously declined, indicating a more sustainable and profitable development than for 1996-2000. One major reason for the decline in losses despite the rising number of vehicles-as discussed in Sect. 2.2. - was a decline in claims frequency thanks to increased technical standards and improvements in vehicle safety (see, e. g., p. 92 in GDV 2005; p. 5 in Swiss Re 2007). 


\section{Analysis of competitive situation—price war or just intense competition?}

Price wars are characterized by competing firms struggling to undercut each other (see Assael 1990). Typically, one firm starts to grab market share by lowering prices and the other market participants follow its lead, resulting in downward price pressure (see Urbany and Dickson 1991). During a price war, companies set prices significantly below the level usually charged in the industry (see Busse 2002) and these prices are not sustainable over the long term (see Schunk 1999). Price wars are a phenomenon found in many industries, including bus rides, tires, and notebook PCs. ${ }^{7}$ They have also been subject to extensive academic analysis, e. g., by Busse (2002) for airlines, Slade (1992) for oil, and van Heerde et al. (2008) for retail, to name just a few.

However, there are very few studies on price competition and, to our knowledge, none explicitly on price wars in the insurance industry. There are two streams to the literature on price competition in insurance: one stream deals with the idea that insurance crises can be explained by preceding soft markets and price cutting (see, e. g., Harrington and Danzon 1994; Harrington et al. 2008); the second stream deals with profit and underwriting cycles. ${ }^{8}$ One reason for the lack of scientific studies on price wars in insurance is lack of data. There are, in most cases, no data on loss forecast revisions to study price-cutting behavior as done for the United States by Harrington and Danzon (1994) and Harrington et al. (2008). Neither are there detailed monthly or weekly price points for single insurers for a significant amount of time as used in the study of other industries, such as retail or airlines. This situation is also true for German motor insurance, for which only aggregate yearly market data on average prices are available.

\subsection{Testing of conditions from price war definitions}

When looking at a market with a competitive situation, it is challenging to determine whether there is just strong price competition or a price war happening (see Heil and Helsen 2001). To help identify whether a strong price competition has developed into a price war, Heil and Helsen (2001) define a price war as requiring one or more of the following conditions: (1) the direction of pricing is downward, (2) the pricing interplay is not sustainable, (3) there is a strong focus on competitors instead of on consumers, (4) the pricing interaction as a whole is undesirable to firms, (5) the competitors did not intend or expect to ignite a price war, (6) the competitive interaction violates industry norms, and (7) the pricing interaction occurs at a much faster rate than normal.

Applying these seven conditions for a price war to the German motor insurance market, we confront the claim made by trade literature maintaining that there have been two recent price wars in the German motor insurance market (1996-1999 and 2005-2006). We can discuss two of the seven conditions based on data presented above in the market overview section.

\footnotetext{
${ }^{7}$ See Table 3 below and Heil and Helsen (2001) for a more detailed overview.

${ }^{8}$ See, e. g., Cummins and Outreville (1987) for an overview. 
1. The situation in the German motor insurance industry clearly supports Condition 1 since price direction was indeed downward for the so-called price war periods, as shown in Figs. 1 and 2. Average premiums - measured by premium per vehicle - decreased by $18 \%$ for the period of 1995-1999 and by $8 \%$ for 2004-2006. In contrast, premiums per contract stayed almost constant for the same periods for the other property-liability lines of business.

2. However, regarding Condition 2, stating that in case of a price war the pricing interplay is not sustainable, e. g., if firms start pricing below cost, the evidence is mixed. While the motor insurance line of business operated at a loss, i. e., with negative technical results for 1997-2002 — within the first period of intense competition-it clearly operated profitably for the second period of intense competition. ${ }^{9}$ In 2005 and 2006, technical results are around 5\%. The conclusion regarding Condition 2 is thus twofold: For the first period of intense price competition, Condition 2 is fulfilled; for the second period, it is not.

Examination of the remaining five conditions is mainly based on industry reports, annual reports by the regulator (BaFin) and the German Insurance Association (GDV), and an analysis of press articles.

3. Condition 3 claims that in case of a price war, insurers focus rather on competitors than on consumers in their competitive interplay. This is clearly the case for the German motor insurance market. As an example, consider the introduction after deregulation of "competitive rebates", which are not risk based, but solely aimed at undercutting competitors' prices (see p. 58 in BAV 1998). The strong focus on price is not necessarily based on customer preferences; rather, it is driven by the insurers themselves. Ghezzi et al. (2005) show in a representative study of the German motor insurance market that only 11\% (in 2000) and 18\% (in 2004) of the customers belong to a market segment with primary focus on price. ${ }^{10}$ Against this, insurers have put their main emphasis on price, rather than on customer service or product innovation.

4. According to Condition 4, in a price war, the pricing interaction as a whole is undesirable to the companies involved. Market participants and also the German Insurance Association stress that the pricing interaction in 1996-1999 led to undesirable losses in the motor insurance line of business (see, e. g., pp. 92-94 in GDV 2005). Also, some insurers expressed their discomfort with the developments in late 2004 and at the beginning of 2005, where Allianz, after three years of steadily increasing prices, suddenly announced premium decreases (see, e. g., Nicolai 2005). However, it is not possible to conclude from these findings whether the pricing interaction during the periods under consideration was more or less desirable than it has been during other time periods.

5. To meet Condition 5 of the price war definition, competitors must not have intended or expected to start a price war. Instead, price wars may be the unintentional result of competitive misunderstandings during periods of market entry,

\footnotetext{
${ }^{9}$ Note that a negative technical result can be cancelled out by a positive investment result.

${ }^{10}$ Maas et al. (2008) come to a similar conclusion in a more recent study for the year 2007, showing that only $22 \%$ of insurance customers in Germany across all lines of business focus primarily on price.
} 
overheating, emotionally driven interaction, or noise in competitive interaction (see Heil and Helsen 2001; Schunk 1999; Axelrod 1997). Analyzing the situation in the German motor insurance market for both periods, we conclude that market participants consciously contributed to an increase in competition. They were fully aware of the intensifying competitive situation. For example, market leaders Allianz and HUK introduced co-brands for cheaper tariffs - Allianz24 and HUK24, respectively - in order to gain market share via price competition (see, e. g., Müller 2005). Also, insurers used alternative direct distribution channels to reach price-sensitive customers by cooperating with retailers, e. g., Direct Line with Karstadt and Zurich with C\&A (see, e. g., Lier 2008). Given these facts, we conclude that Condition 3 is not fulfilled.

6. According to Condition 6, to qualify as a price war, competitive interaction must violate industry norms. For the first period of intense price competition (1996-1999), a violation of industry norms can be observed. This is implied by the annual reports from the regulator and the German Insurance Association. Both entities accuse the industry of competitive and non-risk-based pricing with deviation from the recommendations issued by the industry association (see pp. 58-61 in BAV 1998; pp. 56-57 in BAV 1999). Furthermore, insurers are said to lower prices despite increasing claims payments, leading to significant losses (see pp. 53-54 in BAV 2000), and to introduce a broad range of competitive discounts (see p. 60 in GDV 1999). However, during this period, the insurance industry was in the process of redefining its norms after the changed regulatory situation and was only just beginning to learn how to cope with competitive behavior in a deregulated market. This situation is why market participants in the second period of intense competition (2005 and 2006) cannot be described as violating industry norms but, rather, simply as acting as expected in the face of stiff competition. Thus, once again, the evidence on price wars is mixed.

7. For a price war to be occurring, pricing interaction must appear to be faster than usual (Condition 7). Price changes in the motor insurance market are significantly less frequent and less flexible than in other industries due to the nature of the product and the pricing/underwriting process. As Erdönmez et al. (2007) show in a representative study of the Swiss and German motor insurance market, $74 \%$ of insurers change tariffs only once per year, $17 \%$ two to three times per year, and $9 \%$

Table 2 Conclusion on discussion of price war definition criteria

\begin{tabular}{lll}
\hline Condition & 1996-1999 & 2005-2006 \\
\hline 1. Direction of pricing is downward & & $\checkmark$ \\
2. Competitive interplay is not sustainable & $\checkmark$ & $\checkmark$ \\
3. Focus on competitors instead of consumers & unclear & unclear \\
4. Pricing interactions undesirable to firms & $\times$ & $\times$ \\
5. Competitors did not intend/expect to start a price war & $\checkmark$ & $\times$ \\
6. Competitive interaction violates industry norms & unclear & unclear \\
7. Pricing interaction much faster than normal & & \\
\hline
\end{tabular}

Condition fulfilled $(\checkmark)$; condition not fulfilled $(\times)$ 


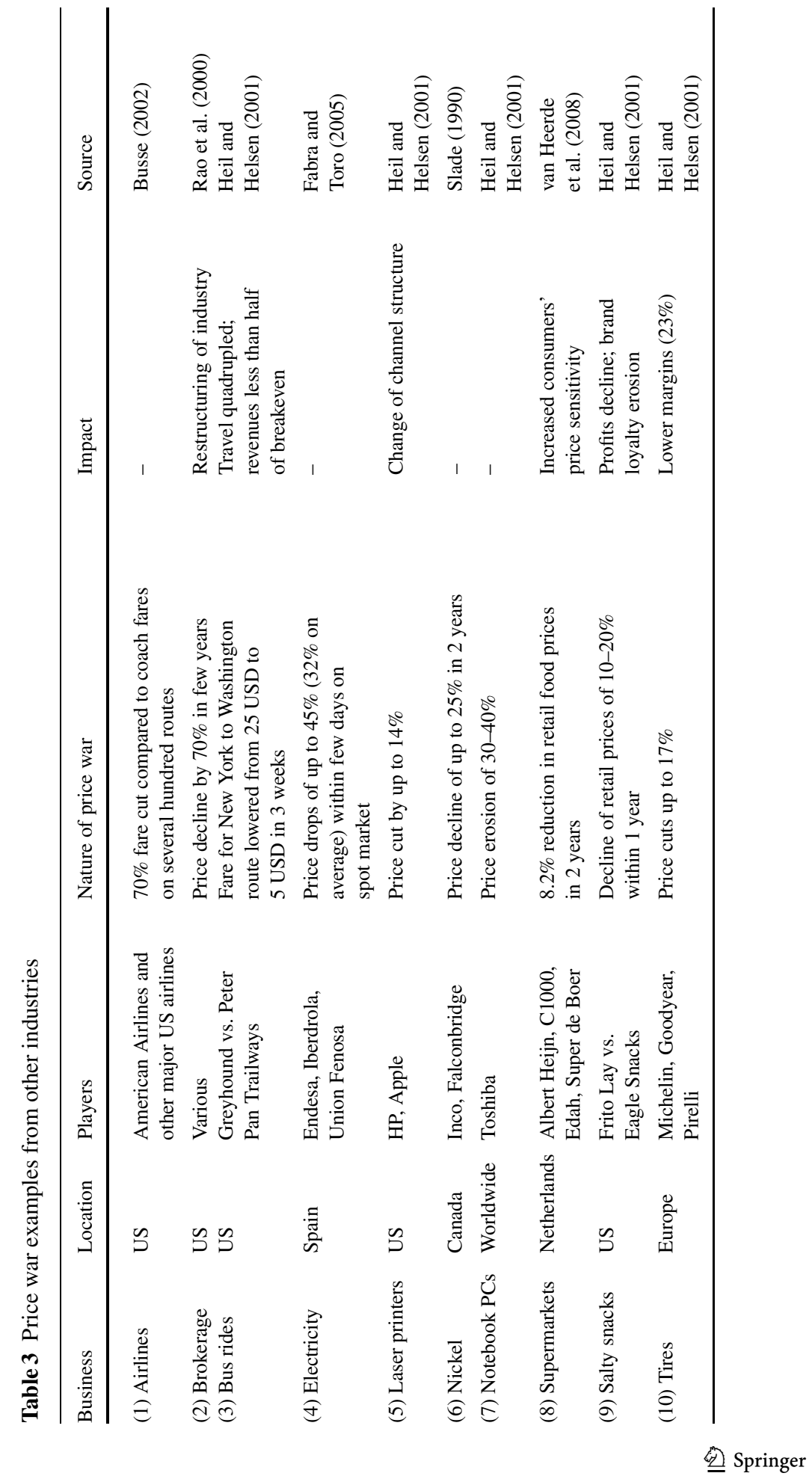


do so more flexibly. The average time needed to implement a price change in this industry is 60 days (e. g., to adapt IT systems and to distribute and explain the new pricing scheme to sales agents). Therefore, principal pricing interactions in insurance are mainly based on annual premium changes. However, more frequent and flexible price changes can be achieved through discounts, which, as shown above, insurers used extensively during 1996-1999 (see p. 60 in GDV 1999; pp. 58-61 in BAV 1998). Unfortunately, it is not possible to analyze effective pricing dynamics in detail due to unavailability of appropriate data.

Table 2 is a summary of the arguments in favor and against the price war hypotheses. Checking the applicability of the seven price war conditions developed by Heil and Helsen (2001) to the motor insurance market gives a result mainly in favor of the price war hypotheses for the period of 1996 to 1999 and mainly against it for 2005 to 2006.

\subsection{Comparison to reference cases from other industries}

Along with examining the conditions posited to prove the existence of a price war proposed by Heil and Helsen (2001), reference cases from other industries that have been studied in academic literature on price wars can provide valuable insights. An overview of 10 examples is provided in Table 3.

Compared to these cases from other industries, the $18 \%$ decrease in average premiums from $1995-1999$ (-4.7\% p.a.) and the $8 \%$ ( $-4.2 \%$ p.a.) decrease in 2004-2006 in German motor insurance are rather low and dispersed over comparably long timeframes. For example, price wars in notebook PCs have led to price erosions of 30-40\% (\#7 in Table 3) and a bus ride fare price war in the US has seen fares for a particular route declining by $80 \%$ within 3 weeks (\#3). ${ }^{11}$ Furthermore, a price war in Dutch supermarkets, a per se low margin business, has led to a decline in retail food prices of over $8 \%$ in 2 years (\#8). ${ }^{12}$ Also, the impact of price wars in other industries seems more severe than it does in the German motor insurance industry.

Although price competition in German motor insurance led to a decline in profitability for some years and increased customers' price sensitivity to a certain degree (see Ghezzi et al. 2005), other industries have been faced with more severe consequences, for example, changes in channel structure (Table 3, \#5), brand loyalty erosion (\#9), or the restructuring of a whole industry as in case of (online)-brokerage (\#2).

\section{Conclusion}

This paper contributes to an understanding of competition in the German motor insurance market, which is the most important line of business in the German propertyliability insurance industry and the subject of intense discussion among practitioners

\footnotetext{
${ }^{11}$ Throughout the discussion of these examples we do not consider the other conditions in these industries, e. g., the decline in prices in the notebook business might be due to reduced costs. The general conditions in the other industries thus might not be exactly comparable to the situation of the motor insurance industry.

${ }^{12}$ For more examples, see Heil and Helsen (2001). 
and in the trade literature in the last several years. The motor insurance market has experienced intense price competition since deregulation of the European insurance markets in 1994. An indicator of this development is the steady decline in premiums per vehicle since 1994 . The average premiums per vehicle declined by $18 \%$ from $€ 484$ in 1994 to $€ 393$ in 2006, whereas average premiums in other lines of property-liability insurance remained stable or increased.

However, according to our findings, particularly when we compared them to price wars in other industries, the German motor insurance industry has not and is not engaged in a price war. For example, the period from 2005 to 2006, which shows a significant decline in average premiums, does not show a decline in profitability, as required by the definition of a price war. Also, the speed and magnitude of price declines in our reference cases from other industries are much higher than in the case of German motor insurance. We would therefore describe the periods of 1996 to 1999 and 2005 to 2006 as times of intense competition, rather than as times of price wars.

Acknowledgements We are grateful to the participants of the 2008 Annual Meeting of the German Insurance Science Association for their valuable suggestions and comments.

\section{References}

Assael, H.: Marketing. Prentice Hall, Englewood Cliffs (1990)

Axelrod, R.: The complexity of cooperation. Princeton University Press, Princeton (1997)

BaFin: Jahresbericht 2006 der Bundesanstalt für Finanzdienstleistungsaufsicht. BaFin, Bonn und Frankfurt am Main (2007)

BAV: Geschäftsbericht 1997, Teil A, Bundesaufsichtsamt für das Versicherungswesen. BAV, Berlin (1998)

BAV: Geschäftsbericht 1998, Teil A, Bundesaufsichtsamt für das Versicherungswesen. BAV, Berlin (1999)

BAV: Geschäftsbericht 1999, Teil A, Bundesaufsichtsamt für das Versicherungswesen. BAV, Berlin (2000)

Busse, M.R.: Firm financial conditions and airline price wars. Working Paper, Yale School of Management, New Haven (2002)

Cummins, J.D., Outreville, J.F.: An international analysis of underwriting cycles in property-liability insurance. J. Risk Insur. 54(2), 246-262 (1987)

Erdönmez, M., Gerber, M., Nützenadel, C.: Pricing-Strategien in der Motorfahrzeug-Versicherung. Institut für Versicherungswirtschaft der Universität St. Gallen (2007)

Fabra, N., Toro, J.: Price wars and collusion in the Spanish electricity market. Int. J. Ind. Organ. 23(3-4), 155-181 (2005)

Farny, D.: The development of European private sector insurance over the last 25 years and the conclusions that can be drawn for business management theory of insurance companies. Geneva Pap. Risk Insur. Issues and Practice 24(2), 145-162 (1999)

GDV: Jahrbuch 1998. Die deutsche Versicherungswirtschaft, Gesamtverband der Deutschen Versicherungswirtschaft e.V., Berlin (1999)

GDV: Jahrbuch 2004. Die deutsche Versicherungswirtschaft, Gesamtverband der Deutschen Versicherungswirtschaft e.V., Berlin (2005)

Ghezzi, G., Markus, M., Sepp, T.: Die Commodity-Falle - und wie Kfz-Versicherer sie meiden können. In: Biswurm, B., Schönwälder, S., Sepp, T. (eds.): Performance Schaden/Unfall 2005, pp. 43-51. McKinsey, Düsseldorf (2005)

Heil, O.P., Helsen, K.: Toward an understanding of price wars: Their nature and how they erupt. Int. J. Res. Mark. 18(1-2), 83-98 (2001)

Harrington, S.E., Danzon, P.M.: Price-cutting in liability insurance markets. J. Bus. 67(4), 511-538 (1994)

Harrington, S.E., Danzon, P.M., Epstein, A.J.: Crises in medical malpractice insurance: Evidence of excessive price-cutting in the preceding soft market. J. Bank. Finance 32(1), 157-169 (2008) 
Hussels, S., Ward, D., Zurbruegg, R.: Stimulating the demand for insurance. Risk Manag. Insur. Rev. 8(2), 257-278 (2005)

Lier, M.: Preisrutsch bei Autopolicen geht weiter. Handelsblatt, 08.01.2008 (2008)

Maas, P., Graf, A., Bieck, C.: Trust, transparency, and technology. European customers' perspectives on insurance and innovation. IBM institute for business value and institute of insurance economics, University of St. Gallen (2008)

Morawetz, M.: Zeit des Erwachens? Versicherungswirtschaft 63(9), 738-740 (2008)

Müller, J.H.: Preiskampf geht weiter. Süddeutsche Zeitung (SZ), 09.06.2005 (2005)

Nicolai, B.: Provinzial macht Preiskampf bei Autoversicherungen nicht mit. Welt Online, 30.06.2005, www.welt.de (2005)

Rao, A.R., Bergen, M.E., Davis, S.: How to fight a price war. Harv. Bus. Rev. 78(2), 107-116 (2000)

Rees, R., Kessner, E., Klemperer, P., Matutes, C.: Regulation and efficiency in European insurance markets. Econ. Policy 14(29), 363-397 (1999)

Reitz, U.: Ohne Rücksicht auf Verluste. Versicherungskaufmann 46(2), 12-17 (1999)

Schmidt-Gallas, D., Lauszus, D., Burger, V.: Das Preisproblem in Kfz ist hausgemacht. Versicherungswirtschaft 60(22), 1736 (2005)

Schunk, H.: The evolution of competitive interaction. Working Paper, University of Mainz (1999)

Seiwert, M.: Weniger radikal - Rolf-Peter Hoenen im Interview. Wirtschaftswoche online, 02.09.2006, www.wiwo.de (2006)

Slade, M.E.: Strategic pricing models and interpretation of price-war data. Eur. Econ. Rev. 34(2-3), 524-537 (1990)

Slade, M.E.: Vancouver's gasoline price wars: An empirical exercise in uncovering supergame strategies. Rev. Econ. Stud. 59(2), 257-276 (1992)

Swiss Re: European motor markets. Swiss Re, Zurich (2007)

Urbany, J., Dickson, P.: Competitive price-cutting momentum and pricing reactions. Marketing Lett. 2(4), 393-402 (1991)

van Heerde, H., Gijsbrechts, E., Pauwels, K.: Winners and losers in a major price war. J. Marketing Res., forthcoming (2008) 